\title{
Opinion \\ White (caucasian!) american heritage month
}

Volume 4 Issue 3 - 2015

\section{Opinion}

(Originally written as "European" American Heritage Month in June, 2008 - but many pressed to change it to "White" American Heritage Month--but it should be CAUCASIAN American Heritage Month as changed February 2015).

This measure would recognize the month of October in every year as Caucasian American Heritage Month

WHEREAS, The Caucasian ancestry of America will be a minority by 2050 in the United States; and

WHEREAS, This Diaspora is diverse in religious beliefs; and

WHEREAS, This Diaspora represents diverse ethnicities including African, Anglo-Saxon, Armenian, Basque, Celtic, Gallic, Germanic, Greek, Iberian, Italic, Scandinavian and Slavic; and

WHEREAS, This Diaspora has led to the establishment of public and private institutions in the United States that are praised by people everywhere in the world; and

WHEREAS, The tremendous contributions by Caucasians in the field of engineering, science and medicine have positively changed the face of this planet; and

WHEREAS, There is hardly an advance, benefit, improvement, or library on earth that has not been started, developed and promulgated by Caucasians; and

WHEREAS, Caucasians are the only group ever promoting the common humanity of all mankind and altruistically celebrating diversity by creating a society supporting minorities in obtaining equal rights to the degree of establishment of its own minority status; and

WHEREAS, Currently there is no official recognition by government agencies and public schools of a specially designated heritage month for Caucasian Americans; and

WHEREAS, There is official recognition for other national origin, continent origin and ethnic groups in many states; and

WHEREAS, There are over 180 million Caucasian Americans in the United States; now, therefore be it

RESOLVED that in the interest of fairness and diversity, the month of October in every year be recognized as Caucasian American Heritage Month to honor and celebrate our Caucasian heritage.

\author{
Samuel A Nigro M.D \\ Retired, Assistant Clinical Professor Psychiatry, Case Western \\ Reserve University School of Medicine, USA \\ Correspondence: Dr. Samuel A Nigro M.D., Retired,Assistant \\ Clinical Professor Psychiatry, Case Western Reserve University \\ School of Medicine, 2517 Guilford Road, Cleveland Heights, \\ Ohio 44I I8, USA, Tel 216 932-0575, Email sam@docnigro.com \\ Received: October 15, 20I5 | Published: November 24, 2015
}

LOOK UP ANYTHING IN ANY ENCYCLOPEDIA....

AND PROBABLY FIND A

CAUCASIAN PERSON OR TWO

PLAYING A LEADING ROLE.

IT IS DIFFICULT TO FIND ANY BENEFIT ANYWHERE

WHICH DOES NOT HAVE A CAUCASIAN PERSON

AS ORIGINATOR OR INSTRUMENTAL

DEVELOPER OR PROMOTER.

\section{Acknowledgments}

None.

\section{Conflicts of interest}

None.

\section{Funding}

None. 